378.147::811.163.41(437.6)

https://doi.org/10.18485/msc_saopstenja.2018.48.1.ch23

Кристина Н. ЂОРЂЕВИЋ*

Univerzita Komenského v Bratislave

Filozofická fakulta
Прегледни рад

Примљен: 20. 10. 2018.

Прихваћен: 03. 12. 2018.

\title{
СРБИСТИКА У СЛОВАЧКОЈ
}

\begin{abstract}
У реферату представљамо рад лектората за српски језик на Филозофском факултету Универзитета Коменски у Братислави, у оквиру којег се као уско стручни предмети усмерени на комуникативну језичку компетенцију изучавају Српски језик $1-5$, Словенски језик 1: српски - Словенски језик 4: српски. Такође се изучавају и предмети погодни за упознавање са српском културом, традицијом, књижевношћу, историјом, кинематографијом: Српске реалије, Српски филм, Увод у студије српске културе и књижевности. Рад пружа увид у тренутно стање и перспективу учења српског језика у Братислави, а посебна пажња посвећена је опису предмета Српске реалије и Српски филм.

Кључне речи: лекторат српског језика, Универзитет Коменски у Братислави, српски језик као страни, Српске реалије, Српски филм.
\end{abstract}

Државни Универзитет Коменски (у даљем тексту УК) најстарији је и највећи универзитет у Словачкој. Настао је 1919. године на темељима Академије Истрополитана (Academia Istropolitana), коју је основао 1465. угарски краљ Матеј Корвин. Универзитет Коменски има тринаест факултета, на којима студира преко 25.000 домаћих студената годишње, а око 2.100 страних студената долази на размену из преко 70 земаља света. Филозофски факултет УК у Братислави, основан 1921. године, најстарији је филозофски факултет у Словачкој. Нуди преко 130 студијских програма на основним, мастер и докторским студијама и омогућава мобилност студената путем билатералних међународних договора. Такође, у понуди је више јединствених студијских програма, међу које спада и српски језик, који се данас на територији Словачке изучава само на УК, у оквиру двопредметног програма дипломских студија под називом Словенске студије (Slovanské štúdiá).

Традиција изучавања српског језика на Филозофском факултету Универзитета Коменски везује се за академску 1922/1923. годину и рад српског лек-

"kristina.dordevic@uniba.sk. 
тора Штефана Влахова (Štefan Vlahov). Међу првим предавачима српскохрватског језика и књижевности истичу се и Франк Волман (Frank Wollman), Валериј Александрович Погоријелов (Valerij Alexandrovič Pogorielov), Милош Вајнгарт (Miloš Weingart). Доласком Риста Ковијанића ${ }^{1}$ године 1927/1928. започела су систематичнија предавања српске и хрватске књижевности и српскохрватског језика на Универзитету Коменски. На Катедри за словенску филологију, која је некада носила назив Катедра за славистику и индоевропеистику, студенти су српскохрватски језик учили најпре у форми лектората, а од академске 1964/1965. године било је могуће одабрати студије српскохрватског језика у комбинацији са словачким језиком и библиотекарством, руским, немачким или енглеским језиком, све до 1995/1996. године, када је српскохрватски као студијски програм последњи (осми) пут отворен (Кулихова, Хвишч 1996: 76). Године 1993, због бурних друштвено-политичких прилика у Републици Словачкој, са Филозофског факултета УК одлази последњи лектор српскохрватског језика Милица Лађевић, што је довело до тога да Катедра за словенску филологију остане без званичног лектора српскохрватског језика. Њега је привремено заменио Михал Бабијак (Michal Babiak) ca Катедре за естетику, држећи предавања из српске и хрватске књижевности, а потом и лекторска вежбања српског језика. Након потписивања билатералног културног договора између Републике Словачке и Републике Хрватске, већ 1994/1995. године долази хрватски лектор, а услед поделе језика на српски и хрватски, српскохрватску филологију наслеђује кроатистика. ${ }^{2}$ Катедра за словенску филологију више пута је посредством Министарства просвете, науке, истраживања и спорта Републике Словачке упућивала захтеве за лектором српског језика Министарству просвете, науке и технолошког развоја Републике Србије, које се није одазивало на молбе да се лектор пошаље, ${ }^{3}$ што је довело до тога да србистика буде маргинализована. Сложићемо се са мишљењем М. Николић (2013: 63) да „до овакве ситуације можда не би ни дошло да је српска страна била мање пасивна и да је Србија, као што то чине друге земље, више штитила своје језичке интересе и улагала у своје лекторате у свету".

Ипак, изучавање српског језика никад није престало, захваљујући привременим решењима које је Катедра за словенску филологију успешно проналазила све до доласка новоименованог лектора за српски језик 2012. године, ${ }^{4}$ чиме је званично основан лекторат српског језика у Братислави (тренутно једини у Словачкој). Током пет година рада лектората српски језик

\footnotetext{
${ }^{1}$ Ристо Ковијанић одликован је за свој педагошки и научни рад 1968. године Златном медаљом Словачке академије наука, а 1987. поводом шездесетогодишњице оснивања лектората српскохрватског језика Медаљом за заслуге Филозофског факултета УК у Братислави (Шкорванкова 2017: 287).

2 Детаљније о томе погледати у Добрикова (2012: 98) и Кулихова (2014: 76).

${ }^{3} \mathrm{O}$ томе в. у Добрикова (2012: 99) и Ђорђевић (2017: 218).

${ }^{4}$ Дужност лектора за српски језик 2012/2013. и 2013/2014. године обављала је Весна Ђорђевић, коју је наследила Кристина Ђорђевић 2014. године. Више информација о томе ко су били лектори за српски језик и предавачи српског језика и књижевности на Катедри за словенску филологију Филозофског факултета УК пружају и радови: Кулихова/Хвишч (1996: 73-79), Добрикова (2012: 99), Кулихова (2014: 73-78) и Ђорђевић (2014: 108-110).
} 
изучавао се само као изборни предмет све до академске 2017/2018. године, када је Катедра за словенску филологију отворила нови двопредметни програм дипломских студија под називом Словенске студије, у оквиру којих је могуће студирати српски језик у комбинацији са другим словенским језиком (бугарским, пољским, словеначким или хрватским), односно у комбинацији са етнологијом или историјом од текуће 2018/2019. године. Прву годину српског језика у оквиру новоотвореног студијског програма Словенске студије 2017/2018. године уписало је и завршило пет студената, а текуће 2018/2019. прву годину српског језика уписало је такође њих петоро. ${ }^{5}$ На лекторату српског језика поред предмета усмерених на језичку компетенцију: Српски језик 1-5, Словенски језик 1: српски - Словенски језик 4: српски, ${ }^{6}$ изучавају се и предмети погодни за упознавање са српском културом, традицијом, књижевношћу, историјом, кинематографијом: Српски филм, Српске реалије, Увод у студије српске културе и књижевности. Сваког семестра реализује се и курс Српски језик за јавност, намењен свима који желе да уче српски језик. Српском језику са теоријског аспекта посвећена су предавања професора Мирослава Дудока Српски језик 1-5, док се српском књижевношћу баве Звонко Танески на предметима Српска књижевност 1-2 и Алица Кулихова на предмету Српска књижевност 3.

Подршку лекторату пружају колеге из Србије на различите начине, као што су, на пример, међуфакултетске размене научног особља или учешће на конференцијама Hudobné motivy vo frazeológii (2014) и Slovanské jazyky, literatúry a kultúry v kontaktoch (2017), које је организовала Катедра за словенску филологију Филозофског факултета УК у Братислави. Народна библиотека Србије редовно помаже лекторат литературом углавном књижевноуметничког, научног и публицистичког садржаја, а не треба заборавити и неколико донација Матице српске. Међународни славистички центар даровао је лекторату више значајних дидактичких издања, а сваке године додељује две стипендије за Скуп слависта, једну намењену студентима, другу предавачима српског језика. О томе, али и о историјату и раду лектората српског језика на Филозофском факултету Универзитета Коменски у Братислави, опширније је писано у радовима Ђорђевић (2014: 105-114) и Ђорђевић (2017: 215-223). Стога, посебну пажњу у даљем тексту посветићемо опису предмета Српске реалије (Reálie Srbska) и Српски филм (Srbský film).

На настави предмета Српске реалије и Српски филм тежи се приступу усмереном ка студентима, у научним круговима познатом као student-centred

\footnotetext{
${ }^{5}$ Студенти србистике уписани 2017/2018. године на програм Словенске студије одабрали су следеће комбинације: српски језик и хрватски језик (двоје), српски језик и словеначки језик (троје), а исто је и у 2018/2019. години.

${ }^{6}$ Предмети Словенски језик 5: српски и Словенски језик 6: српски представљају надградњу за студенте који су успешно апсолвирали предмете Словенски језик 1 : српски - Словенски језик 4: српски, а желели би да наставе са учењем српског језика. До сада су курсеви Словенски језик 5: српски и Словенски језик 6: српски реализовани само 2012/2013. године под вођством тадашњег лектора за српски језик Весне Ђорђевић.
} 
learning approach. ${ }^{7}$ Наравно, није увек могуће остварити све циљеве и имплементирати све методе и технике оваквог приступа. Ипак, лектор се труди да у сарадњи са студентима дефинише теме и задатке, који су у складу са интересовањима, знањем и искуствима студената и договара се око термина завршног испита и презентација. Самостални рад студената (презентација и есеј/семинарски рад) доноси велики проценат предиспитних обавеза, чиме је постигнуто да студенти преузимају одговорност за учење, односно да сами одређују колико ће амбициозно приступити својим задацима, али и да сопственом брзином задовоље потребе индивидуалног учења. Употреба слика, видео и аудио материјала неопходна је како би се стимулисало више чула, а повезивањем садржаја са локалним примерима учење постаје релевантно за њихово искуство. Практичне демонстрације (на пример, у оквиру разговора о ускршњим обичајима студенти су се такмичили у туцању јајима) обезбеђују стварно искуство студентима. Применом образовних игара, квиза или асоцијације, проверава се да ли су исходи учења остварени.

Један од циљева наставе представља и стицање интеркултурне компетенције, чијим се усвајањем превазилазе стереотипи и предрасуде, а истовремено се развија толеранција према другој култури. Интеркултурна компетенција постиже се стицањем знања о другој култури, развијањем свести о другачијим перспективама, посматрањем себе и других (Момчиловић 2013: 527). Шира заједница препознала је потребу да се интеркултурно образовање уведе у наставу, те су међународне споразуме и конвенције прихватили Унеско, Савет Европе и Европска унија са циљем да ученици разумеју различитост у друштвима.

Унеско дефинише културу као „скуп различитих духовних, материјалних, интелектуалних и емоционалних образаца одређеног друштва или друштвене групе [...], обухватајући и књижевност, животни стил, начине друштвеног организовања, системе вредности, традицију и веровања" (Унеско 2002: 18). Ослањајући се на овако дефинисан појам културе, на часовима Српских реалија и Српског филма студенти се упознају са специфичностима српске културе, као што су обрасци свакодневног понашања, популарна култура, историја, кинематографија, географија, књижевност, сликарство, музика, спорт, обичаји и веровања. Један од важнијих циљева наставе јесте да студенти стекну интеркултурну компетенцију, односно да развијају толеранцију, емпатију, прилагодљивост и критички став према концептима етноцентричности и стереотипима (на пример, филмови Емира Кустурице повод су за разговор о положају Рома у Србији и Словачкој). На овај начин студенти се припремају и за одлазак у нову средину. У даљем тексту ближе ћемо представити структуру предмета Српске реалије и Српски филм.

Једносеместрални предмет Српске реалије, чији је главни циљ упознавање студената са Србијом и српском културом, први пут је одржан 2015/2016. године, са недељним фондом од два часа. До сада је испит поло-

\footnotetext{
${ }^{7}$ Више о приступу student-centred learning в. у монографији A Guide to Student-Centred Learning (Брендес/Гинис 2001).
} 
жило тридесет шест студената (тринаесторо 2015/2016, десеторо 2016/2017. и 2017/2018. тринаесторо), а текуће 2018/2019. године уписано је десеторо студената. Полазници курса могу бити сви студенти Универзитета Коменски у Братислави, због чега се настава одвија на словачком језику. Наставни план предмета обухвата неколико области:

- Кратак преглед историје Србије, њене културе и књижевности

- $\quad$ Географске и демографске одлике Србије

- Српско културно (материјално и нематеријално) наслеђе записано у Унеску

- $\quad$ Туризам и гастрономија

- Српски фолклор и народни обичаји

- Значајни представници српске књижевности, уметности, позоришта, филма и музике.

Предиспитне обавезе студената, осим похађања наставе и активног учешћа у њој, чине израда семинарског рада и његова презентација на часу. Понуђене теме за семинарски рад из различитих су области, нпр.: Дунавом кроз Србију, Путевима римских императора, Национални паркови Србије, Развој српског филма, Историја Савезне Федеративне Републике Југославије.

На уводном часу студенти се упознају са концептом предмета Српске реалије, темама које ће се обрађивати и својим предиспитним обавезама. За многе од њих ово је први контакт са Србијом, српским језиком и српским културолошким особеностима, те је важно на самом почетку приближити им ове садржаје скретањем пажње на постојање српско-словачких културно-историјских веза. ${ }^{8}$ Осим тога, на часовима се указује и на културолошке разлике (на пример, обичаји - новогодишњи, божићни и ускршњи, перцепција времена и простора и др.). Уводни час се завршава а сваки наредни почиње квизом, који обухвата градиво са претходног часа, те, уколико остане времена, предавање се завршава песмом одабраног српског музичког извођача. Завршни испит студенти полажу у писаном облику, у форми теста на словачком језику, или српском, уколико наставу похађају студенти на размени из Србије.

Главни проблем при извођењу наставе представља недостатак литературе на словачком језику и мањак културних садржаја, ${ }^{9}$ у Братислави пре свега, повезаних са Србијом и српском културом, које би студенти посећивали.

За предмет Српски филм предвиђена су четрдесет и два сата у току семестра, односно три часа недељно. Главни циљ курса је да студентима пружи основне информације у вези са српском кинематографијом друге половине

\footnotetext{
${ }^{8}$ Од великог значаја за указивање на српско-словачке културно-историјске везе јесте монографија Srbi u Slovačkoj. Srbi na Slovensku (Церовић 1999), као и доступни видео снимци са датом тематиком.

${ }^{9}$ Решење би могло бити отварање српског културног центра у Братислави, што би значајно помогло лекторату, али и допринело промовисању Србије, српског језика и културе у иностранству. Док се то не деси, Амбасада Републике Србије требало би активније да организује различите културне догађаје, као што то чини, на пример, Амбасада Републике Словеније у Братислави.
} 
XX века и прве деценије XXI века. Кратак наставни план предмета обухвата неколико целина:

- Историја развоја српског филма

- $\quad$ Теме савременог српског филма

- Номинације и награде српских филмова и глумаца

- Национални тематски филмски фестивали

- $\quad$ Приказивање филмова српске кинематографије и њихова интерпретација.

Завршно оцењивање студената обухвата презентацију одабраног филма/ глумца/режисера, коју прати есеј и тест на крају семестра. Наводимо неколико тема којима су се студенти бавили: Документарни филм у Србији, Дело Емира Кустуриче, Ко то тамо пева - анализа филма, Историјска потка филма Монтевидео, Бог те видео, Екранизована српска књижевна дела и др. До сада је предмет апсолвирало четрдесет пет студената (шесторо 2013/2014, троје 2014/2015, ${ }^{10}$ једанаесторо 2015/2016, шеснаесторо 2016/2017. и деветоро 2017/2018), а текуће 2018/2019. уписано их је дванаесторо. Литературу за предмет чине скрипта састављена од стручних и новинских чланака преведених на словачки језик, као и одабрани делови монографија Јане Дудкове Balkán alebo metafora: balkanizmus a srbský film 90. rokov (2008) и Línie, kruhy a svety Emira Kusturicu (2001).

Изазов за лектора представља одабир филмова за приказивање, који се некад доноси у складу са доступношћу филма, али и према афинитетима студената. Текуће академске године биће приказана следећа филмска остварења: Ко то тамо пева Слободана Шијана (1980), Маратонци трче почасни круг Слободана Шијана (1982), Варљиво лето '68 Горана Паскаљевића (1984), Лепа села лепо горе Срђана Драгојевића (1996), Лајање на звезде Здравка Шотре (1998), Црна мачка, бели мачор Емира Кустурице (1998), Седам и по Мирослава Момчиловића (2006), Монтевидео, Бог те видео Драгана Бјелогрлића (2010), Парада Срђана Драгојевића (2011).

Значај предмета Српске реалије и Српски филм вишеструк је: студенти преузимају одговорност за учење, развија се интеркултурна компетенција, уочавају се разлике и сличности између своје и друге културе, развија се свест о стереотипима и предрасудама, што доприноси прихватању и поштовању другачијег. Коначно, можда најважнији циљ јесте приближити студентима Србију, српску културу и српски језик.

У раду смо настојали да укратко представимо историјски развој и рад лектората српског језика на Филозофском факултету Универзитета Коменски у Братислави. Сматрамо да су представљени предмети Српске реалије и Српски филм добар пример педагошке праксе употпуњавања студија садржајима за које често не остаје времена на часовима српског језика.

Чињеница је да постоји интересовање студената за студирање српског језика, што доказује отварање студијског програма Словенске студије,

${ }^{10}$ Године 2013/2014. и 2014/2015. предмет Српски филм реализовао се под називом Српски филм 1 (Srbský film 1). 
у оквиру којег је могуће одабрати студије српског језика већ другу годину заредом. Зато је важно да се уложе напори, како предавача на Катедри за словенску филологију, чија добра воља постоји, тако и надлежних институција Републике Србије, не би ли се одржало и унапредило постојеће стање лектората српског језика у Словачкој. ${ }^{11}$

\section{ЛИТЕРАТУРА}

Брандес/Гинис 2001: D. Brandes, P. Ginnis, A Guide to Student-Centred Learning, United Kingdom: Nelson Thome Ltd.

Добрикова 2012: M. Dobríková, Jazykovedná slavistika na Katedre slovanských filológií Filozofickej fakulty Univerzity Komenského v Bratislave, y: P. Žeňuch (ред.), Slovenská slavistika včera a dnes, Bratislava: Slovenský komitét slavistov, Slavistický ústav Jána Stanislava SAV, 94-105.

Дудкова 2001: J. Dudková, Línie, kruhy a svety Emira Kusturicu, Bratislava: Slovenský filmový ústav.

Дудкова 2008: J. Dudková, Balkán alebo metafora: balkanizmus a srbský film 90. rokov. Bratislava: Slovenský filmový ústav, Veda.

Ђорђевић 2014: В. Ђорђевић, Лекторат српског језика на Филозофском факултету Универзитета Коменски у Братислави, Наш језик, XLV/3-4, $105-114$.

Ђорђевић 2017: К. Ђорђевић, Лекторат српског језика у Братислави, Книжевна историја 63, Београд: Институт за књижевност и уметност, 215-223.

Крајишник 2014: В. Крајишник, Лекторати српског језика, у: С. Танасић (ред.), Зборник Института за српски језик САНУ II. Српски језик и актуелна питања језичке политике, Београд: Институт за српски језик САНУ, 217-226.

Кулихова/Хвишч 1996: A. Kulihová, J. Hvišč, Ostatné slovanské filológie (Chorvatistika, srbistika, slovinistika, bohemistika), y: J. Hvišč, J. Mravík (ред.), Štúdium slovanských filológii na Filozofickej fakulte Univerzity Komenského v Bratislave, Bratislava: T.R.I. Médium, 73-79.

Кулихова 2014: A. Kulihová, Od srbochorvátčiny k chorvátčine a srbčine, y: M. Dobríková, M. Vojtech (ред.), Philologica 73, Bratislava: Univerzita Komenského, 73-78.

Момчиловић 2013: Н. Момчиловић, Интеркултуралност и настава страних језика, у: Б. Димитријевић (ред.), Наука и савремени универзитет 2, Од науке до наставе, Ниш: Филозофски факултет, Универзитет у Нишу, $523-535$.

\footnotetext{
${ }^{11} \mathrm{O}$ предлозима за побољшање положаја лектората српског језика у литератури је више пута писано. Без претензија на библиографску исцрпност, наводимо неколико студија: Стипчевић (2007: 262-263), Крајишник (2011: 5), Ђорђевић (2014: 111), Крајишник (2014: 220-224), Ђорђевић (2017: 220-221).
} 
Николић 2013: М. Николић, Србистика на Петроградском универзитету данас, Наш језик, XLIV/3-4, 59-70.

Стипчевић 2007: С. Стипчевић, Српски у Италији, у: М. Дешић (ред.), Сpnски као страни језик у теорији и пракси, Београд: Филолошки факултет, Центар за српски као страни језик, 255-266.

Унеско 2002: UNESCO, Universal Declaration on Cultural Diversity.

$<18$ http://unesdoc.unesco.org/images/0012/001271/127162e.pdf > 5. 10. 2018.

Церовић 1999: Lj. Cerović, Srbi u Slovačkoj. Srbi na Slovensku, Bački Petrovac: Kultura; Novi Sad: Društvo srpsko-slovačkog prijateljstva.

Шкорванкова 2017: E. Škorvanková, Risto Kovijanić a jeho pôsobenie na Filozofickej fakulte Univerzity Komenského v Bratislave, y: M. Slobodník, M. Glossová (ред.), 95 rokov Filozofickej fakulty UK. Pohl'ad do dejín inštitúcie a jej akademickej obce, Bratislava: Univerzita Komenského, 275-291.

\section{Kristina N. Đorđević}

\section{SERBIAN STUDIES IN SLOVAKIA}

\section{Summary}

In the paper we will present the work of lectorate of Serbian language at the Faculty of Philosophy at Comenius University in Bratislava. We will give an insight into the current situation and perspectives on learning Serbian language in Bratislava. Special attention will be dedicated to the description of the subjects Serbian Facts (Reálie Srbska) and Serbian Film (Srbský film), whose main goal is to introduce students to Serbia and Serbian culture.

Key words: lectorate of Serbian language, Comenius University in Bratislava, Serbian language as foreign language, Serbian Facts, Serbian Film. 